\section{Kvasnytsia 0., Rusin V.}

\title{
RESEARCH OF RESERVES OF STRENGTHENING THE INCOME BASE OF BUDGETS OF UNITED TERRITORIAL COMMUNITIES IN DECENTRALIZATION CONDITIONS
}

Об’єктом дослідження є теоретичні та практичні аспекти формування дохідної бази бюджетів об’єднаних територіальних громад в умовах децентралізації. Одним із найбільи проблемних місць об'єкту дослідження є перерозподіл повноважень та джерел формування фінансових ресурсів для їх реалізащї між рівнями бюджетної системи. Процес децентралізацї пов'язаний із складністю та тривалістю впровадження ефективної системи забезпечення населення суспільними послугами належного рівня та якості. У роботі з'ясовано, яка кількість громад добровільно об'єдналася та яку площу територї та чисельності населення Украӥни охоплено. Проведено аналіз сучасного стану формування дохідної бази бюджетів об'єднаних територіальних громад в умовах реалізації реформи децентралізащіі.

У прочесі дослідження використано загальнонаукові та спеціальні методи дослідження у їх взаємозв'язку й взаємодіі. Зокрема абстрактно-логічні прийоми дозволили з'ясувати, чим спричинені проблеми, які виникають у процесі формування дохідної бази бюджетів об'єднаних територіальних громад. Серед них є брак професійних кадрів в територіальних громадах та неналежна організація співпращі виконавчих органів громад із іншими учасниками бюджетного процесу.

Визначено напрями зміцнення дохідної бази бюджетів об’єднаних територіальних громад, що передбачають заходи:

- щодо детінізацї доходів найманих працівників та розвитку підприємництва на територіӥ громади, що забезпечить можливість збільшення надходжень до бюджету від сплати податку на доходи фізичних осіб;

- спрямовані на вдосконалення системи адміністрування місцевих податків $і$ зборів, зокрема щодо встановлення ставок та пільг;

- спрямовані на легалізацію суб'єктами господарювання роздрібної торгівлі підакцизних товарів;

- щодо ефективного використання майна громади;

- спрямовані на розширення переліку надання адміністративних послуг.

Завдяки цьому органи місцевого самоврядування об'єднаних територіальних громад отримають більше ресурсів у свойх бюджетах, які зможуть використати на створення комфортних умов проживання у громаді.

Ключові слова: умови децентралізащї, доходи бюджету, місцевий бюджет, об'єднана територіальна громада, місцеві податки і збори.

\section{Introduction}

In the conditions of development of a democratic society in Ukraine, local government plays an important role in providing the population with public services. One of the key conditions for the proper performance by local governments of such functions is the availability of a sufficient level of financial resources accumulated in the budget. The success of the socio-economic development of not only society, but also the region and the state as a whole depends on how well the revenue base of the budgets of territorial communities meets the needs.

Over the years of Ukraine's independence, the budgetary system has been characterized by the centralization of financial resources, the unevenness of their distribution throughout the state, the financial insolvency of local budgets, and a significant differentiation of budget expenditures on the provision of public services at the local level. In order to eliminate these shortcomings, at the end of 2014, the leadership of the state launched the reform of decentralization in Ukraine, which was based on conceptually new approaches to building a system of functioning of local self-government and the territorial organization of power in Ukraine. The main achievement of the reform was the voluntary unification of territorial communities, giving them the authority to independently resolve issues of local importance, as well as the ability to form their own resource base to ensure the implementation of these powers.

The implementation of this reform in practice demonstrates certain difficulties and problems associated both with the very unification of territorial communities and with the full use of already united communities of all possibilities for building and strengthening their income base. That is why the study of ways to strengthen the revenue base of the budgets of the united territorial communities 
in the context of decentralization is an urgent problem and requires further solutions.

\section{The object of research and its technological audit}

The object of research is the theoretical and practical aspects of the formation of the revenue base of the budgets of the united territorial communities in the context of decentralization. The reform of the decentralization of power and financial resources of the state in favor of local self-government demonstrates positive dynamics and yielded noticeable results. At the end of 2018, more than 850 united territorial communities were created, the area of which makes up almost $40 \%$ of the total area of Ukraine and where $25 \%$ of the population of the total population of Ukraine live. Due to this, since the beginning of the reform, the share of local budget revenues in the consolidated budget, the share of local taxes and fees in the local budget own revenues is growing annually [1].

Despite significant achievements, certain difficulties and problems arise in the formation of the revenue base of the budgets of the united territorial communities in the context of decentralization:

- creation of a part of united communities without taking into account the requirements of the methodology according to their ability;

- lack of adequate staffing of local governments;

- possession and use of the property of the company;

- cooperation of local governments with other execu-

tive authorities in Ukraine;

- lack of readiness for the independent exercise of their powers by local authorities.

Not all united territorial communities have local governments showing interest in increasing revenues to their budgets, searching for possible reserves to increase them, and improving the efficiency of the system for administering taxes and fees received in their budgets.

The reform of decentralization, which allows local governments to form their own revenue base of budgets for the implementation of an expanded list of powers, can be considered one of the most successful reforms since Ukrainian independence. However, this reform has not yet been completed, in turn, expands the field of activity for further research with the possibility of implementing foreign experience in Ukrainian practice.

\section{The aim and objectives of research}

The aim of research is determination of the reserves for increasing the revenue base of the budgets of the united territorial communities.

To achieve the aim of research the following objectives are defined:

1. To study the theoretical and practical aspects of the formation of the revenue base of the budgets of the united territorial communities.

2. To identify the existing problems of formation of the revenue base of the budgets of the united territorial communities.

3. To scientifically substantiate proposals for ways to strengthen the revenue base of the budgets of the united territorial communities.

\section{Research of existing solutions of the problem}

The problems of the formation of financially wealthy, independent territorial communities devoted a significant amount of scientific work. In foreign countries (including European) in the second half of the twentieth century, reforms were actively pursued aimed at increasing the revenue base of local budgets and expanding the budgetary powers of local self-government. In the economic literature, these reforms are covered mainly in the plane of fiscal decentralization $[2,3]$.

In [4], the author emphasizes that most scientists are focused on assessing the experience of decentralization throughout the world and the search for a correspondence between theory and practice. At the same time, much less attention is paid to implementation strategies. The author offers implementation recommendations - twelve «rules» that can form the basis of a decentralization strategy. The sixth «rule» concerns the formation of a revenue base for local budgets, in which the author defines a list of taxes that can and cannot be used by local authorities. However, the author ignores the powers of local governments to collect these taxes and control this process.

The author of the work [5] notes that local governments should have the right to independently determine the volume and structure of expenditures and incomes, which, by their nature, should correspond to the local level of government. The author, citing the example of Germany, notes that the expenditures of municipalities are de facto guided by the available resources. Local governments are limited in matters of tax policy and dependent not only on the central government, but also on the federal one. Let's agree with the statement that the formation of financial resources even at the expense of self-setting insignificant rates of local taxes and fees will always be better than any kind of transfer. However, let's consider it unacceptable to describe the experience of the limited powers of local authorities in the context of increasing the revenue base of their budgets.

Focusing on the availability of a significant amount of literature on the distribution of income between different levels, the author of [6], considerable attention in the study focuses on the impact on subnational (local) transfer finance, which is due to the vertical imbalance in local budget revenues. Let's believe that the main attention should be focused on the possibilities of forming the revenue base of local budgets at the expense of taxes and fees, and not transfers.

One of the first in Ukraine interest in the issues of financial independence and autonomy of local governments is shown by the authors of works [7, 8]. The author of [9] argues that the local budget own revenues are revenues that are formed as a result of actions and decisions taken by local governments, resulting in requirements that they must simultaneously meet [10]. Let's support the views of the author and consider it appropriate to develop them.

In a study [11], the authors cite certain constraints designed to help international development partners take into account the relevance of political economy issues to their programmatic support for decentralization and local government reform. The intention of their research is better understanding how political and institutional dynamics influence or may affect the ability to implement 
decentralization reforms aimed at achieving the goals of service delivery, management and poverty reduction. In this study, attention is mainly focused on the powers and influence of various authorities; not enough attention has been paid to the role of these sources of community financial resources.

Thus, the results of the analysis of literary sources allow to conclude that in Ukraine the reform of decentralization is carried out much later than in most foreign countries and has not yet been completed. Territorial communities, united only master the basics of forming their financial base. The main focus of research by scientists is to determine the suitability of the composition of income sources and the powers of local governments to mobilize them. Therefore, the search for reserves to strengthen the revenue base of the budgets of the united territorial communities is promising in the context of the socio-economic development of territories, which requires further research.

\section{Methods of research}

During the research, general scientific and special research methods were applied in their interrelation and interaction:

- search and bibliographic - to search and systematize printed sources on research issues;

- methods of analysis and synthesis, selective research - to analyze the theory and practice of forming the revenue base of the budgets of the united territorial communities; - abstract-logical - to summarize the problematic aspects of the formation of the revenue base of the budgets of the united territorial communities and the rationale for their growth.

\section{Research results}

The revenue base of local budgets should reach such a volume that could provide opportunities to exercise the powers of territorial authorities to provide the population with an adequate level of public services and socio-economic development of the territory. The main achievement of the decentralization reform in Ukraine was that territorial communities were able to consolidate significant amounts of financial resources in their budgets. This is achieved through the redistribution of national taxes and the introduction of new local taxes and fees. The growth rate of revenues to the budgets of the united territorial communities is ahead of that in other levels of local budgets. Due to this, the share of local budgets in the consolidated budget is growing, namely: from $45.6 \%$ in 2015 to $51.2 \%$ in 2017. According to forecasts, in 2018 this figure will reach $51.5 \%$. The share of own revenues (total fund) of local budgets of Ukraine in the volume of GDP also grows, from $5.1 \%$ in 2015 to $6.5 \%$ in 2017. According to the results of 2018, this figure is expected to reach $7.1 \%$ (Fig. 1).

In the structure of revenues of the budgets of united communities, a significant role is assigned to the own re- venues of local budgets, among which the personal income tax provides the greatest revenue (Fig. 2). In addition, the own revenues of the budgets of the united territorial communities are formed at the expense of excise tax revenues, land charges, a single tax, a real estate tax.

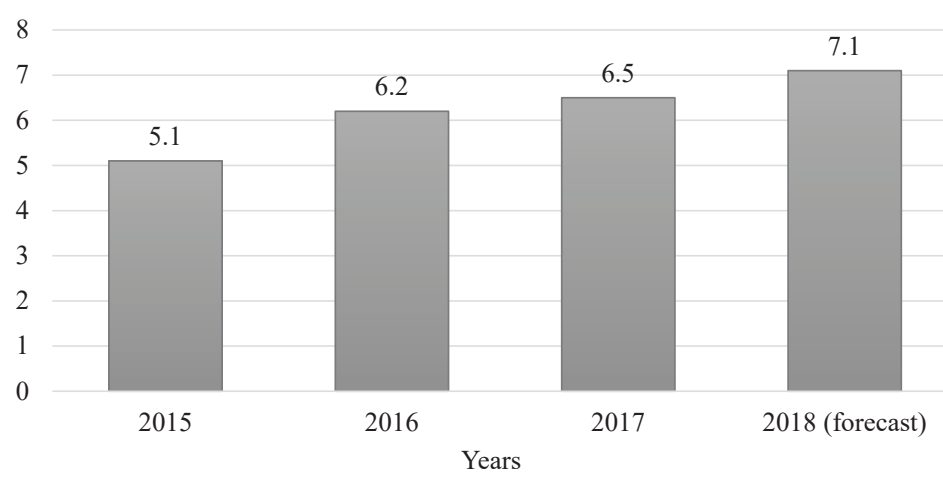

ig. 1. The share of own revenues (total fund) of local budgets of Ukraine in GDP for 2015-2018, \% (developed on the basis of data [1])

million c.u.
700.00
600.00
500.00
400.00
300.00
200.00
100.00
0.00

Fig. 2. Own revenues of the budgets of the united territorial communities for 2017-2018, million c. u. (developed on the basis of data [1])

Despite the fact that the territorial communities after association received a much wider list of taxes and fees that are credited to their budgets, some communities suffer from a lack of financial resources. First of all, it concerns those communities that are created without taking into account the requirements of the methodology according to their ability. As a result, small communities were formed in terms of population and area, while obtaining a low resource potential. However, there are also small communities in whose territories business entities with significant fiscal capacity are located and function, which gives them the opportunity to receive substantial revenues to their budget from paying taxes and fees.

In individual communities, due to the lack of professional staffing of local governments, use of the potential of available financial resources is ineffective. Such communities are not able to absorb the funds received from the state in the form of subventions for the development of communities, to qualitatively prepare investment projects to receive funds from the state fund for regional development, to attract international grants [12].

The current state of the democratic development of Ukraine, taking into account the positive results of 
decentralization and the existing unsolved problems, requires the efforts of local governments to strengthen the revenue base of the budgets of their territorial communities. In the context of the incompleteness of the initiated reform, there are reserves for increasing revenues, particularly in the context of improving the efficiency of the system of administration of taxes and fees.

In the structure of revenues of the budgets of the united territorial communities, the lion's share is accounted for by the personal income tax - within $50-80 \%$. It is the leader in terms of annual growth. The increase in the volume of income from personal income tax is due to a certain extent to the legalization of wage payments, positive trends in the increase in minimum social guarantees and growth the size of the minimum wage during 2016-2018. Despite the significant fiscal role of this payment in the formation of the revenue part of community budgets, the system of administration of this tax is characterized by the possibility of increasing revenues from the payment of this tax.

Despite a number of measures by the state to legalize wages, including the use of weighty penalties, there is still a certain level of income shadowing of employees. The labor inspectors of the State Employment Service, as well as the labor inspectors of the executive bodies of the councils of the united local communities, can check on compliance with labor legislation in the form of inspection visits and out-of-home inspections. However, only an insignificant part of united territorial communities has such labor inspectors in their staff. In most communities, they are not ready to bear the expenses from the budget for the maintenance of such workers in the staff of the executive body of the company. However, the presence of such workers in the communities can provide not only supervisory functions, but also provide an opportunity to conduct awareness-raising work on compliance with labor legislation among employers who work in the community.

The receipt of tax on personal income is taken into account when determining the amount of basic or reverse subsidies. In practice, there have been cases when the community leadership believed that overestimated volumes of reverse subsidies are being withdrawn from their budgets for using statistical data from the State Statistics Service of Ukraine when calculating these transfers. The number of registered residents of the community was not consistent with the statistics. This is the case when the funds were transferred to the community budget, but their part was transferred to the state budget, while losing the available financial resources from paying personal income tax.

In the context of increasing revenues to the budgets of territorial communities from the tax on personal income, it is not enough just measures for the legalization of wages, which can be implemented through control and administrative measures, and through informational and explanatory. To increase revenues from this type of payment in the future, it is necessary to carry out comprehensive work for local authorities to attract investment in the community, stimulating the development of entrepreneurship. Efforts should be made to create new jobs in society.

Statistics show the expansion of the revenue base of local budgets due to local taxes and fees. The share of local taxes and fees in own revenues of local budgets reaches $30 \%$. Such revenues are secured through property tax receipts, a single tax, a charge for parking spaces and a tourist tax. It is in this group that the community's budget revenues have significant potential for increasing revenues. Tax rates on real estate, other than land, which are established by local authorities, even within neighboring communities, are very different. In many communities, individuals who own residential and non-residential real estate apply a symbolic real estate tax rate and provide benefits to a wide circle of the community's population. The use of an unreasonably low tax rate does not justify the effort and expense of administering this tax. In this case, the possibility of increasing revenues from real estate taxation lies in the planar efforts of local authorities in society.

Another problematic issue in levying real estate tax is the process of its administration. This is due to the lack of full databases with information on taxable items. Information on registered rights and their encumbrances today is open and publicly available, including for local government officials. However, the capabilities of the software product, which is used in its activities by the bodies of state registration of rights to real estate do not provide the possibility of generating information about the full list of real estate objects for a specific administrativeterritorial unit. Therefore, due to the lack of technical possibilities to form a database on taxable objects, efforts are being minimized on mechanisms to counter evasion of real estate tax. In the context of this, it is necessary to strengthen the cooperation of the executive bodies of companies with the territorial bodies of state power in the exchange of information related to taking into account taxpayers and exercising control over the payment of taxes and obligatory payments.

Discussions are continuing in scientific circles regarding the expediency of using the area or the estimated value of real estate as a base for taxing real estate property. However, here the terms of reference of local self-government are limited. Such decisions are made by adopting relevant laws at the state level. It is worth noting that, in foreign experience, it is primarily the assessed value that is used as the basis for calculating real estate tax [13]. The reserve for the growth of revenues of the budgets of the united territorial communities can be considered income from the payment of excise tax on the sale of excisable goods by retail entities. Upon receipt of the excise tax on excisable goods (products) in terms of full, then the circulation of the realized fuel is sufficiently controlled by the central executive authorities. However, in terms of excise tax revenues from sales of excisable goods by retail business entities, there is considerable potential for their increase. In a number of similar budgets of united territorial communities, data on revenues are radically different. This is evidence that in certain communities, the sale of a significant part of excisable goods by retail business entities is likely to be carried out without issuing fiscal checks. This allows them to understate the excise tax owed to the community budget from the sale of excisable goods by retail entities. Communities consume much more excisable goods than are officially sold by retail businesses. This is confirmed by the statistical studies of the World Health Organization on the consumption of alcohol and tobacco products per capita at the age of 15 years [14, 15].

Consequently, the reserve for increasing revenues from the payment of excise tax on the sale of excisable goods 
by retail business entities is significant. To do this, local authorities need to make efforts to conduct preventive awareness-raising work among businesses engaged in retail trade in the community. The community should realize that by demanding a check at the store when buying alcoholic and tobacco products, they will ensure that the excise tax is paid to the community budget for the sale of excisable goods by retail entities. Residents should understand that if the community budget has more revenues, respectively, more public services they can receive, or these funds, for example, can be used to develop community infrastructure. Therefore, outreach activities are also needed among the community population.

The potential for increasing community budget revenues is in expansion of powers of local authorities in the formation of non-tax revenues. This applies to property owned by the community. Quite often there are cases when in the community itself do not have reliable information about the property that belongs to them. In some communities, there are no clear mechanisms for transferring property for rent and calculating rental payments. Quite often the property that is being rented is significantly underestimated. These issues of concern negatively affect the generation of income from the use of community property. By making efforts to fully inventory the property of the community and provide transparent rules for leasing it, it is possible to obtain more revenue to the community budget.

Another reserve for increasing revenues to the budgets of united territorial communities is the expansion of the list of administrative services in the community. Aware of this reserve in many communities opened the Centers for the provision of administrative services. As a result, the community population was able to receive a number of services on the spot (for example, paperwork for a passport), and the budget in return received additional financial resources.

\section{SWOT analysis of research results}

Strengths. The strengths lie in the fact that the proposed measures to strengthen the revenue base of the budgets of united territorial communities can be implemented in most communities throughout Ukraine, which will increase their financial security. Compared to peers, the proposed study does not require changes to the laws of Ukraine, but allows to attract more financial resources to the community budget precisely because of the revitalization of the activities of local governments themselves in the context of making effective management decisions. The strength of the fact is that local governments, if there is a large amount of financial resources at their disposal, will be able to provide the population of the community with better public services.

Weaknesses. The weak side of the study is the reluctance or inability of local authorities to independently implement the proposed directions for practical implementation. When introducing individual proposals, local governments will have to incur additional costs, in particular when opening the Centers for the provision of administrative services or when introducing a post of labor inspector. Increasing the fiscal role of local taxes and fees in society can be very negatively perceived by the community population. In addition, increasing pressure on business entities operating in the community may lead to the cessation of their activities, resulting in a community budget deficit income.
Opportunities. It should be noted that there is an opportunity for further research in the search for new directions of practical implementation of the proposed activities. Since the rates of local taxes and fees and benefits for their payment is an effective mechanism for the formation of financial resources of territorial communities, their optimal application requires separate research. With increasing financial security of territorial communities, the need arises for further research in the context of finding ways to use financial resources efficiently. These studies may be interesting for those communities that have not yet merged in the decentralization process.

Threats. Threats to the results of the research are that even the implementation of all activities in practice may not provide an adequate level of financial security for the territorial community. As a result, the community population will not receive the expected level of public services. The situation is complicated by the fact that the implementation of individual proposals requires increased pressure on taxpayers and payers, which can lead to the opposite of the expected effect - reduction of financial resources in budgets.

\section{Conclusions}

1. It is determined that the number of communities voluntarily united in the context of the decentralization reform, it is determined what area of the territory and population of Ukraine covered this process. The analysis of the formation of the revenue part of the budgets of the combined territorial communities of 2017-2018 is carried out. It is found out at the expense of which types of own revenues the revenue base of the budgets of the united territorial communities is formed. It is determined what percentage of GDP is redistributed through own revenues (total fund) of local budgets. The analysis makes it possible to state that regional communities receive substantial amounts of financial resources at their disposal than those which does not voluntarily join.

2. The existing problems of forming the revenue base of the budgets of the united territorial communities are identified. Existing problems are caused by:

- formation of small communities;

- lack of professional staffing in local government;

- inadequate organization of cooperation of the executive bodies of the united communities with the population, business entities and central executive authorities.

3. It is established that in united territorial communities there is still a significant potential for increasing the revenue base of their budgets. It is proposed:

- a number of measures to eliminate the incomes of employees and develop entrepreneurship in the community to increase revenues to the budget from the payment of personal income tax;

- measures to improve the system of administration of local taxes and fees, in particular to establish the rates and benefits for real estate tax;

- measures for the legalization of retail goods by excisable goods by economic entities;

- measures to increase non-tax revenues, in particular regarding the effective use of property owned by the community, and expanding the list of administrative services in the community. 


\section{References}

1. Monitorynh protsesu detsentralizatsii vlady ta reformuvannia mistsevoho samovriaduvannia. 10.11.2018. Ministerstvo rehionalnoho rozvytku, budivnytstva ta zhytlovo-komunalnoho hospodarstva Ukrainy, 2018. URL: https://storage.decentralization.gov.ua/uploads/library/file/333/10.11.2018.pdf

2. Oates W. E. Fiscal Federalism. New York: Harcourt Brace Jovanovich Inc., 1972. 256 p.

3. Buchanan J. M., Musgrave R. A. Public finance and public choice: Two contrasting visions of the state. Cambridge: MIT Press, 1999. 272 p. doi: http://doi.org/10.7551/mitpress/5688.001.0001

4. Bahl R. Implementation Rules for Fiscal Decentralization. 1999. 23 p. URL: http://siteresources.worldbank.org/INTDSRE/Resources/3p.pdf

5. Tsimmermann Kh. Munitsipal'nye finansy: textbook. Moscow: Delo i Servis, 2003. 352 p.

6. de Mello L. Local Government Finances: The Link between Intergovernmental Transfers and Net Worth. OECD Economics Department Working Papers. No. 581. Paris: OECD Publishing, 2007. doi: http://doi.org/10.1787/18151973

7. Vasylyk O. D. Pro finansovu nezalezhnist orhaniv mistsevoho i rehionalnoho samovriaduvannia:proceeding // Aktualni problemy upravlinnia terytoriiamy v Ukraini. Kyiv, 1993. P. 120-122.

8. Tkachuk I. H. Ekonomichna samostiinist rehionu: monograph. Kyiv: Naukova dumka, 1994. 227 p.

9. Mistsevi finansy: textbook / ed. by Kyrylenko O. P. Ternopil: Ekonomichna dumka TNEU, 2015. 448 p.

10. Kyrylenko O. P. Finansova nezalezhnist mistsevoho samovriaduvannia // Finansy Ukrainy. 2001. Issue 1. P. 34-39.
11. Kent E., Kai K., Smoke P. J. The Political Economy of Decentralization Reforms: Implications for Aid Effectiveness. Directions in Development. Public sector governance. Washington: World Bank, 2011. 92 p. URL: http://siteresources.worldbank. org/EXTDSRE/Resources/DecentralizationReforms.pdf

12. Analitychna dopovid do shchorichnoho Poslannia Prezydenta Ukrainy do Verkhovnoi Rady Ukrainy «Pro vnutrishnie ta zovnishnie stanovyshche Ukrainy v 2018 rotsi». 2018. URL: http:// www.niss.gov.ua/doslidzhennya/naukovi-vidannya/poslannyaprezidenta-ukraini/analitichna-dopovid-do-schorichnogo

13. Almy R. Valuation and Assessment of Immovable Property OECD Working Papers on Fiscal Federalism. No. 19. OECD 2014. doi: http://doi.org/10.1787/5jz5pzvr28hk-en

14. Pure alcohol consumption, litres per capita, age 15+. European Health Information Gateway. 2018. URL: https://gateway.euro. who.int/en/indicators/hfa 426-3050-pure-alcohol-consumptionlitres-per-capita-age-15plus/

15. Percent of regular daily smokers in the population, age $15+$ European Health Information Gateway. 2018. URL: https:// gateway.euro.who.int/en/indicators/hfa_421-3010-of-regulardaily-smokers-in-the-population-age-15plus/

Kvasnytsia Oksana, PhD, Associate Professor, S. I. Yurii Depart ment of Finance, Ternopil National Economic University, Ukraine, e-mail: o.kvasnytsia@tneu.edu.ua, ORCID: http://orcid.org/00000003-3003-7616

Rusin Viktor, PhD, Associate Professor, S. I. Yurii Department of Finance, Ternopil National Economic University, Ukraine, e-mail: viktor.rusin@gmail.com,ORCID: http://orcid.org/0000-0002-4155-189 